\title{
Economically Productive Features of Turkeys Breed in Azerbaijan
}

\section{Azerbaycan'da Üretilen Hindilerin Ekonomik Açıdan Üretim Özellikleri}

\author{
Research Article \\ Minura Kazimova \\ Azerbaijan State Agricultural University, Department of Veterinary, Ganja, Azerbaijan.
}

\section{A B S T R AC T}

Turkey breeding is an important source of increased production of high-quality bird meat. Many years of experience shows the effectiveness of industrial turkey breeding. Among the meat species of poultry, the turkey occupies a special place. By its biological and economic characteristics, it is one of the most promising species of meat poultry. Turkeys have a high fertility and high yield of edible parts per unit of live weight. The aim of the research was creating new highly productive breeds, lines and to study the dynamics of the economic-useful qualities of turkeys of various lines, breeds and productive, interior features, quality of meat of turkeys breed in the conditions of Azerbaijan.

\section{Key Words}

Poultry farming, turkey, turkey meat, red meat, quality, meat production, white meat.

\section{öz}

LI indi yetiştiriciliği yüksek kaliteli kuş eti üretiminin önemli bir kaynağıdır. Uzun yıllara dayanan tecrübeler - endüstriyel hindi ıslahının etkinliğini göstermektedir. Kanatı hayvan eti türleri arasında hindiler özel bir yere sahiptir. Hindiler yüksek doğurganlık ve canlı ağırlığın birimi başına yenilebilir kısımlarının fazla olması nedenile önemli et kaynaklarından biridir. Araştırmanın amacı yeni, yüksek üretken hatlar oluşturmakla beraber Azerbaycan koşullarında yetişdirilen hindilerin çeşitli hatlarının üretkenliyini, iç mekan özelliklerini, kalitesini, ekonomik yararlı niteliklerinin dinamikliyini incelemekten ibarettir.

\section{Anahtar Kelimeler}

Kümes hayvanları yetiştiriciliği, hindi, hindi eti, kırmızı et, kalite, et üretimi, beyaz et.

Article History: Received: Nov 11, 2017; Revised: Dec 06, 2017; Accepted: Feb 15, 2018; Available Online: Mar 26, 2018.

DOI: $10.15671 /$ HJBC.2018.230

Correspondence to: M. Kazimova, Azerbaijan State Agricultural University, Department of Veterinary, Ganja, Azerbaijan. 


\section{INTRODUCTION}

$Y$ oung domestic turkeys readily fly short distances, perch and roost. These behaviors become less frequent as the birds mature, but adults will readily climb on objects such as bales of straw. [1,2]Young birds perform spontaneous, frivolous running ('frolicking') which has all the appearance of play. Commercial turkeys show a wide diversity of behaviors including 'comfort' behaviors such as wing-flapping, feather ruffling, leg stretching and dust-bathing [3].

Turkeys are highly social and become very distressed when isolated [4,5]. Many of their behaviors are socially facilitated i.e. expression of a behavior by one animal increases the tendency for this behavior to be performed by others [6-8]. Adults can recognise 'strangers' and placing any alien turkey into an established group will almost certainly result in that individual being attacked sometimes fatally [9]. Turkeys are highly vocal, and 'social tension' within the group can be monitored by the birds' vocalisations [10]. A high-pitched trill indicates the birds are becoming aggressive which can develop into intense sparring where opponents leap at each other with the large, sharp talons, and try to peck or grasp the head of each other $[5,11]$. Aggression increases in frequency and severity as the birds mature [12].

Male domestic turkey sexually displaying by showing the snood hanging over the beak, the caruncles hanging from the throat, and the 'beard' of small, black, stiff feathers on the chest $[13,14]$.

Maturing males spend a considerable proportion of their time sexually displaying. [15] This is very similar to that of the wild turkey and involves fanning the tail feathers, drooping the wings and erecting all body feathers, including the 'beard' (a tuft of black, modified hair-like feathers on the centre of the breast) [16]. The skin of the head, neck and caruncles (fleshy nodules) becomes bright blue and red, and the snood (an erectile appendage on the forehead) elongates, the birds «sneeze〉 at regular intervals, followed by a rapid vibration of their tail feathers $[13,17]$. Throught the birds strut slowly about, with the neck arched backward, their breasts thrust forward and emitting their characteristic 'gobbling' call [18-20].
Experimental studies were conducted in private farms. The productive and pedigree qualities of turkeys of all breeds of lines were estimated on the basis of studying such indicators as: live weight, egg production over 20 weeks, egg mass, fertilization and hatchery, turkey output, young animals safety, feed costs, body article measurements, breast musculature and others.

\section{MATERIALS and METHODS}

Turkeys of all sex and age groups were fed with feed-mixtures prepared by the firm «Sheker Yem» in the republic. From the diurnal to 4 week old age, all turkeys, without separation by sex, were kept on the floor and grown to 16 weeks of age. At 16 weeks of age, they were separated by sex and subsequently grown separately.

From the 18th week of age, the females are transferred to a limited light day (under our conditions for 7 hours), the males were grown at 14-15 hours light, the illumination is 15 lux. Density of growing of young turkey at the age of 1-16 weeks 4 heads $/ \mathrm{m}^{2}, 17-30$ weeks 3 heads $/ \mathrm{m}^{2}$. Density of growing of adult birds females 2 head $/ \mathrm{m}^{2}$, males 1 goal $/ \mathrm{m}^{2}$. The feeding front at the age of 1-16 weeks $4 \mathrm{~cm}$ per head, at the age of $17-30$ weeks $8 \mathrm{~cm}$ per head. The front of drinking at the age of 1-16 weeks $2 \mathrm{~cm}$ per head, at 17-30 weeks $3 \mathrm{~cm}$. During the growing of daily young animals the temperature in the room is maintained at $28-30^{\circ} \mathrm{C}$ : under the brooder $35-37^{\circ} \mathrm{C}$, then it is reduced by $3-6^{\circ} \mathrm{C}$, bringing to $18^{\circ} \mathrm{C}$ by the end of the 6th week of growing. The temperature in the room from 7 to 16 weeks of age is maintained at least $17-18^{\circ} \mathrm{C}$, over 16 weeks of age, not below $16^{\circ} \mathrm{C}$. The relative humidity in the turkey room is maintained at $60-70 \%$.

Growth, development and preservation of turkeys. An important indicator that characterizes the level of productivity of turkeys is their live weight and energy of its growth. The results of our studies showed that with the same feeding and maintenance technology, the live weight of the experimental turkeys varied in different ages (Table 1). At the diurnal age, the live weight of the turkeys of the North Caucasian breed group was $55.92 \mathrm{~g}$, which is $5.92 \mathrm{~g}$ or $11.84 \%$ more than in the turkeys of the Local populations ( $B>0.999)$. Further studies 
Table 1. Dynamics of live weight of turkeys of different crosses.

\begin{tabular}{|c|c|c|c|}
\hline & \multirow{2}{*}{ Age, days } & \multicolumn{2}{|c|}{ Breed and populations } \\
\hline & & Local populations & «North-Caucasus» \\
\hline & 1 & $50.00 \pm 0.11$ & $55.92 \pm 0.13$ \\
\hline & 56 & $1807 \pm 103.15$ & $2800 \pm 106.74$ \\
\hline \multirow{3}{*}{91} & Males & $3523 \pm 115.69$ & $4951 \pm 118.25$ \\
\hline & Females & $4645 \pm 116.18$ & $6955 \pm 119.43$ \\
\hline & On average & 4084 & 5953 \\
\hline \multirow{3}{*}{112} & Males & $4748 \pm 152.67$ & $6584 \pm 147.86$ \\
\hline & Females & $6452 \pm 141.95$ & $9156 \pm 139.56$ \\
\hline & On average & 5600 & 7870 \\
\hline \multirow{3}{*}{140} & Males & $5860 \pm 123.43$ & $8111 \pm 120.75$ \\
\hline & Females & $8240 \pm 119.96$ & $11713 \pm 116.67$ \\
\hline & On average & 7050 & 9912 \\
\hline
\end{tabular}

have shown that the genotype shows a significant effect on the growth and development of turkeys. At 56 days of age ( 8 weeks) the turkeys of the North Caucasian breed exceeded the peers of the local population by $993 \mathrm{~g}$, or $54.95 \%$ (B> 0.999). At the age of 91 days, females and males of the North Caucasian breed exceeded the peers of the local population by $1428 \mathrm{~g}$, respectively, or $40.53 \%$ and $2310 \mathrm{~g}$, or $49.73 \%$ ( $\mathrm{B}>0.999$ ).

A similar pattern has been preserved in the following age periods. At 112 days old, the live weight of females and males of the North Caucasian breed was more than that of the peers of the Local
Populations, by $1836 \mathrm{~g}$ respectively, or $38.67 \%$ and $2704 \mathrm{~g}$, or $41.91 \%$ (B > 0.999).

At the age of 140 days the live weight of females and males of the North Caucasian breed was more than in the peers of the Local populations by $2251 \mathrm{~g}$, respectively, or by $38.41 \%$ and $3473 \mathrm{~g}$, or by $42.15 \%$ (B > 0.999).

On average, females and males of the North Caucasian breed exceeded the analogues of the Local populations in the live weight at the age of 91 days for $1869 \mathrm{~g} \mathrm{(45.76 \% );} \mathrm{at} \mathrm{the} \mathrm{age} \mathrm{of} 112$ days-2270g (40.53\%); at the age of 140 day 2862

Table 2.Indicators of growth intensity of experimental turkeys.

\begin{tabular}{|c|c|c|c|}
\hline & \multirow{2}{*}{ Age, days } & \multicolumn{2}{|c|}{ Breed and populations } \\
\hline & & Local populations & «North-Caucasus» \\
\hline & 1 & $50.00 \pm 0.11$ & $55.92 \pm 0.13$ \\
\hline & 56 & $1807 \pm 103.15$ & $2800 \pm 106.74$ \\
\hline \multirow{3}{*}{91} & Males & $3523 \pm 115.69$ & $4951 \pm 118.25$ \\
\hline & Females & $4645 \pm 116.18$ & $6955 \pm 119.43$ \\
\hline & On average & 4084 & 5953 \\
\hline \multirow{3}{*}{112} & Males & $4748 \pm 152.67$ & $6584 \pm 147.86$ \\
\hline & Females & $6452 \pm 141.95$ & $9156 \pm 139.56$ \\
\hline & On average & 5600 & 7870 \\
\hline \multirow{3}{*}{140} & Males & $5860 \pm 123.43$ & $8111 \pm 120.75$ \\
\hline & Females & $8240 \pm 119.96$ & $11713 \pm 116.67$ \\
\hline & On average & 7050 & 9912 \\
\hline
\end{tabular}


g (40.59\%). The study of the growth intensity of experimental turkeys also showed significant differences. More intensively grew and developed turkeys of the North Caucasian breed (Table 2). Absolute growth of live weight for the entire period of their growing was higher than for peers of Local populations by $2856.08 \mathrm{~g}$ or $40.80 \%$, respectively.

An important indicator of the growth of young animals is the average daily increase in live weight. The results of our studies indicate that the turkeys of the North Caucasian breed exceeded the peers of the Local populations by the average daily weight gain for the period from 1 to 56 days at $17.04 \mathrm{~g}$ (51.87\%); for the period from 57 to 91 days at 25.03 g 38.47\%; for the period from $92 \mathrm{~g}$ to 112 day at $19.10 \mathrm{~g}(26.46 \%)$; for the period from 113 to 140 days at $21.14 \mathrm{~g}(40.82 \%)$; for the entire period of growing (20 weeks) at $20.55 \mathrm{~g}$ or $40.81 \%$.

The growth energy of turkeys is determined by the relative increase in live weight. The highest relative increase was in the turkeys of the North Caucasian breed. For the entire period of growing turkeys of the North Caucasian breed highly significantly exceeded the peers of the Local populations in this indicator, respectively, by 3625.32 absolute percent. It should be noted that the highest growth energy in turkeys of all experimental groups is observed for the first time 8 weeks after birth. In the future, the energy of growth is reduced. Thus, the relative increase in live weight in the turkeys of the Local populations decreased by 3488.11 by the 20 week age, and by the North Caucasian breed by 4881.20 absolute percent. An important zoo-technical economic indicator is the preservation of young animals during the growing period. The profitability of turkey farming is largely depended from this indicator. The results of our studies showed a slight difference in the safety of the turkeys of the experimental groups (Table 3).

Preservation of turkeys for the entire period of growing was $93-95 \%$ in the experimental groups. The reason for the withdrawal of turkeys in all groups was mainly mechanical injuries. It should be noted good viability of turkeys of all experimental groups, which confirms the possibility of growing both the local populations and the North Caucasian breed under industrial production conditions.

Feed conversion in turkeys. The most important zoo-technical and economic indicator of the intensity of growth and the productive action of feed are the costs of feed and nutrients of the ration per unit of output.

A study of the dynamics of feed costs per unit of growth in live weight showed that the turkeys of the experimental groups consumed a different number of feeds and unequally paid for food with products. During the eight weeks of growing on one head of turkeys of the North Caucasian breed was spent for $846 \mathrm{~g}$ more mixed feed, than in turkeys of local populations. Despite the greater intake of feed, turkeys of the North Caucasian breed had better feed payment by a gain of live weight. They spent 1 $\mathrm{kg}$ of increase in live weight less on $0.78 \mathrm{~kg}$ of mixed feed and $9.33 \mathrm{MJ}$ of exchange energy than their peers from local populations. During the growing period from 57 to 91 days, turkeys of the North Caucasian breed spent $1 \mathrm{~kg}$ increase of live weight $0.56 \mathrm{~kg}$ less than feed and $6.89 \mathrm{MJ}$ of exchange energy compared with turkeys of local populations.

A similar picture was observed in subsequent periods of growing and fattening. So, during the breeding periods from 92 to 112 days and from 113

Table 3. Preservation of experimental turkeys.

\begin{tabular}{ccccc}
\hline \multirow{2}{*}{ Age, days } & \multicolumn{2}{c}{ Local population } & \multicolumn{2}{c}{ North-Caucasus } \\
\cline { 2 - 5 } & head & $\%$ & head & 100 \\
\hline 1 & 100 & 100 & 97 & 97 \\
\hline 56 & 96 & 96 & 96 & 96 \\
\hline 112 & 94 & 94 & 95 & 95 \\
\hline 140 & 93 & 93 & 95 & 95
\end{tabular}


to 140 days the turkeys of the North Caucasian breed exceeded the peers of the cross "Universal" for the payment of feed increase in live weight by 0.5 and $0.95 \mathrm{~kg}$ and $1 \mathrm{~kg}$ increase in the live weight, respectively, spent correspondingly less at 6.03 and of $11.02 \mathrm{MJ}$ of exchange energy, respectively. It should be noted that in all experimental groups, the increase in feed costs per unit of growth in live weight occurred with age. The highest feed costs were during the growing period from 113 to 140 days in the crossbreeds of the cross «Local Population» $6.24 \mathrm{~kg}$, and in the North Caucasian breed $5.29 \mathrm{~kg}$.

Over the entire period of growing (from 1 to 140 days), the North Caucasian breed turkeys outperformed peers from local populations paying for feed increase in live weight by $0.71 \mathrm{~kg}$ and $8.61 \mathrm{MJ}$ of exchange energy. On the basis of the conducted studies, it can be concluded that turkeys of the North Caucasian breed in all age periods outperform peers from local populations in terms of live weight, absolute average daily, relative growth, preservation and conversion of feed. To intensify the production of turkey meat, we recommend growing turkeys of the North Caucasian breed, which have high quality and low feed costs per unit of production.

\section{RESULTS and DISCUSSION}

A morecomplete understanding of meat qualities can be obtained only after the slaughter of turkeys, as the quantitative and qualitative characteristics of the produce become available. Turkey is one of the largest agricultural birds. According to V. Guschina, V.A.Kanivets. (2012), the fattening period of turkeys is determined by sex, breed and the purpose of their use. In this connection, the production of turkeys is subdivided into a light class (broilers) when fattening for 12-14 weeks, the middle class (turkeys) when fattening 20-24 weeks and the heavy class (turkeys) more than 20-24 weeks, at processing of which 3 weight groups of gutted carcasses are obtained: broilers up to $4.5 \mathrm{~kg}$, female turkeys 4.5 $7.2 \mathrm{~kg}$ and male turkeys more than $7.2 \mathrm{~kg}$.

The results of sorting the carcasses of females and males by category are shown in Table 4 .

It is established that the females of the North Caucasian breed exceeded the cross peers "Local Population" by the quality of carcasses. Most carcasses of females of the North Caucasus

Table 4.The results of the evaluation of turkey carcasses by category.

\begin{tabular}{|c|c|c|c|c|}
\hline \multirow{3}{*}{ Indicator } & \multicolumn{4}{|c|}{ Breeds } \\
\hline & \multicolumn{2}{|c|}{ Local population } & \multicolumn{2}{|c|}{ North-Caucasus } \\
\hline & head & $\%$ & head & $\%$ \\
\hline \multicolumn{5}{|c|}{ Females } \\
\hline Total & 47 & 100 & 47 & 100 \\
\hline $\begin{array}{l}\text { Including: } \\
\text { 1st category }\end{array}$ & 37 & 78.72 & 42 & 89.36 \\
\hline 2nd category & 10 & 21.28 & 5 & 10.64 \\
\hline Non-standards & - & - & - & - \\
\hline \multicolumn{5}{|c|}{ Males } \\
\hline Total & 46 & 100 & 48 & 100 \\
\hline $\begin{array}{l}\text { Including: } \\
\text { 1st category }\end{array}$ & 33 & 71.74 & 41 & 85.42 \\
\hline 2nd category & 13 & 28.26 & 7 & 14.58 \\
\hline Non-standards & - & - & - & - \\
\hline
\end{tabular}


(89.36\%) were classified in the first category, which is $13.51 \%$ more than in females of local populations. The second category included $21.28 \%$ of the carcasses of females of local populations, which was larger than the cross of non-standard carcasses when females were slaughtered. During assessing the quality of male carcasses, it is established that $85.42 \%$ of carcasses belong to the first category in the North Caucasian breed, this is $13.68 \%$ more than that of local populations. The smallest number of carcasses of males of the second category (14.58\%) was in the North Caucasian breed. Nonstandard carcasses were absent in males. Thus, it can be concluded that more qualitative carcasses are obtained from females and males of the North Caucasian breed than from peers of local populations.

Studying the slaughter and meat qualities of turkeys showed that females of the North Caucasian breed have high slaughter characteristics (Table 5). They outperform their peers of local populations on before slaughter weight at $2.24 \mathrm{~kg}$, or $38.62 \%$ (B> 0.999 ), by weight of the eviscerate carcass $2.09 \mathrm{~kg}$, or $42.14 \%$ ( $B>0.999$ ), by weight of gutted carcass at $1.82 \mathrm{~kg}$, or $41.18 \%$ (B>0.999), slaughter output by 1.40 absolute percent.

The control slaughter of males also showed significant differences in the meat qualities between the experimental groups. The turkeys of the North Caucasian breed were significantly more reliable than peers in the local population on before slaughter weight at $3.43 \mathrm{~kg}$, or $42.03 \%$ (B>0.999), by weight of eviscerate carcass at $3.19 \mathrm{~kg}$, or $44.24 \%$ (B>0.999), by weight of gutted carcass at $2.78 \mathrm{~kg}$, or $43.99 \%$ (B>0.999), slaughter output by 1.07 absolute percent, respectively.

Thus, we can conclude that the turkeys of the North Caucasian breed have the best slaughter and meat qualities and are highly superior to the peers of the local populations.

Table 5. Meat quality of experimental turkeys.

\begin{tabular}{|c|c|c|}
\hline \multirow{2}{*}{ Indicator } & \multicolumn{2}{|c|}{ Cross } \\
\hline & «Local population» & «North-Caucasus» \\
\hline \multicolumn{3}{|c|}{ Females } \\
\hline The number of dead females, heads & 47 & 47 \\
\hline Pre - slaughter weight of female, $\mathrm{kg}$ & $5.80 \pm 0.12$ & $8.04 \pm 0.14$ \\
\hline Weight of eviscerate carcass, $\mathrm{kg}$ & $4.96 \pm 0.08$ & $7.05 \pm 0.09$ \\
\hline From pre-slaughter weight, $\%$ & 85.52 & 87.69 \\
\hline Weight of gutted carcass, $\mathrm{kg}$ & $4.42 \pm 0.07$ & $6.24 \pm 0.08$ \\
\hline Slaughter output, $\%$ & 76.21 & 77.61 \\
\hline \multicolumn{3}{|c|}{ Males } \\
\hline The number of dead males, heads & 46 & 48 \\
\hline Pre - slaughter weight of female, $\mathrm{kg}$ & $8.16 \pm 0.13$ & $11.59 \pm 0.12$ \\
\hline Weight of eviscerate carcass, $\mathrm{kg}$ & $7.21 \pm 0.10$ & $10.40 \pm 0.09$ \\
\hline From pre-slaughter weight, $\%$ & 88.35 & 89.73 \\
\hline Weight of gutted carcass, $\mathrm{kg}$ & $6.32 \pm 0.09$ & $9.10 \pm 0.11$ \\
\hline Slaughter output , $\%$ & 77.45 & 78.52 \\
\hline
\end{tabular}




\section{CONCLUSIONS}

Turkeys of the North Caucasian breed in all age periods excel peers of local populations in terms of live weight, absolute average daily, relative growth, and preservation. On average, females and males of the North Caucasian breed exceeded the analogues of local populations by live weight at the age of 91 days in $1869 \mathrm{~g} \mathrm{(45.76 \% );} \mathrm{at} \mathrm{the} \mathrm{age} \mathrm{of} 112$ days on $2270 \mathrm{~g}(40.53 \%)$; in the 140 day old on $2862 \mathrm{~g}$ (40.59\%). Turkeys of the North Caucasian breed have a high feed conversion.

\section{References}

1. F. Alekseyev, O. Vorokova, Turkeys from the Moscow region. Poultry farming 9 (2012) 5-6.

2. B.Belenkiy, Features of industrial production of turkey meat. Poultry farming 6 (2007) 22.

3. GOST 230042-86, Meat and meat products. Methods for determining fat. Standard Inform, (2010).

4. H.M. Hajiyev, Feeding technology of young birds. Azer Publishing, Baku (1987) 32-42.

5. E.E. Epimakhova, The scientific and practical justification for increasing the yield of hatching eggs and conditioned young animals of agricultural birds in the early postnatal period: author's abstract. dis. of the dr. of the agricultural sciences, Stavropol, (2013) 43

6. V.V. Gushin, V.N. Makhonina, V.A. Kanivets, L.A. Shinkarenko, Quality indices of meat of gutted turkey carcasses, Meat industry, 3 (2011) 12-15.

7. M.F. Zonov, Technological methods for increasing the productivity of turkeys and eggs: auto ref. Dr. of agric. Sciences (2011) 45
8. G.M.Erastov, Nutritional value of poultry meat Poultry farming 3 (2014) 28-30.

9. V.A. Kanivets, O.N. Petrukhin, L.A. Shinkarenko, Molecular genetic analysis of two linear crosses Local Population, Innovative developments and their familiarization in industrial poultry farming: XVII International Conference of the Russian Branch of the World Scientific Association for Poultry Farming. (2012) 68-70.

10. V.A. Pogodaev, O.N. Petrukhin, L.A. Shinkarenko, Development and productivity of turkeys of white broad-chested breed in the breeding poultry plant "North-Caucasian Zone Experimental Station for Poultry Farming, Zootechnics. 1 (2015) 28-29.

11. V.A. Pogodaev,V.A. Kanivets, L.A. Shinkarenko, Genetic parameters of breeds of turkeys bred in North Caucasian Zone Experimental Station for Poultry, Bird and poultry products. 3 (2013) 19-22.

12. V.I.Fisinin, The rate for development, Poultry farming. 2 (2015) 2-6.

13. A.I. Shevchenko, Systems of turkey breeding. Bird and poultry products. 6 (2010) 23-25.

14. F.F. Alekseyev, A.V. Aralov, L.S. Belyakova, Under the generaledit.Meat poultry farming.St. Petersburg.:Lan, (2007) 416

15. L.A.Shinkarenko, V.A.Pogodaev, The development of new genotypes of domestic turkeys and their use for the production of environmentally friendly products. Monograph-Cherkessk: BIC, North Caucasus. GGTA, (2014) 156.

16. Flock, Diet mar K. Poultry breeding-the next 25 years, Poultry Processing, 1 (2009) 22-23.

17. Battery cages in EU declining but still dominant. World Poultry.net, 2010, 16 June.

18. Clements, Mark. Poultry export to Europe could face new hurdles, Poultry Int., 8 (2010) 4.

19. Morrison' scon firm free-range for all own label eggs, World Poultry.net, (2010) 13April.

20. Pet and Gerrys introduces heirloombreed blue eggs, World Poultry. net, (2010) 16 March. 